\title{
Central Asian States: Matching Military Means to Strategic Ends
}

\author{
Vitaly Gelfgat *
}

Over the past two decades of independent history, the Central Asian states (Kazakhstan, Kyrgyzstan, Tajikistan, Turkmenistan and Uzbekistan) have developed pragmatic and largely non-ideological national security strategies rooted in their perceptions and prioritization of the complex regional realities. The states' attempts to match their military and security services capabilities to handle a variety of external and internal security challenges highlights the fact that the Central Asian states regard these capabilities as critical elements of hard power. At the same time, while often utilized to help quell various sources of domestic instability, all Central Asian militaries have lacked up-to-date operational experience. A review of their tactical proficiency in dealing with internal conflicts shows that although Kazakhstan and Uzbekistan have contained socio-political unrest better than Kyrgyzstan and Tajikistan, all the states struggled to reform and adapt their armed forces to successfully deliver on their doctrinal obligations. This is because they have remained largely outside of contemporary international military interventions such as Operation Iraqi Freedom, the International Security Assistance Force or Kosovo Forces.

This paper outlines the national security objectives of the Central Asian states and analyzes available information on the size, funding, combat readiness and the overall performance of the militaries in recent domestic conflicts. In attempting to effectively respond to the security challenges envisioned in the respective national defense strategies and doctrines, all Central Asian militaries have often struggled with fundamental operational issues and acted in similarly heavy-handed fashion. The continuous balancing of Russian, U.S. and Chinese regional security agendas aided by reform and modernization of the armed services are important to ensuring the Central Asian militaries' successes in fulfilling their current doctrinal obligations. An examination of the great magnitude of challenges faced by the Kyrgyz and Tajik militaries reveals a particularly compelling explanation for their strategic reliance on Russia in the event of a state emergency.

The collective Central Asian military experience of handling recent internal instabilities suggests that as long as a military establishment is capable of containing security challenges in a relatively short period of time and without causing politically unacceptable casualties, it is unlikely to undergo major structural changes. Provided these states' stability is maintained and a restive area resumes government control, a combination of

\footnotetext{
Captain Vitaly Gelfgat is a Eurasian Foreign Area officer in the U.S. Army. He received his BA and MA in International Policy Studies from the Monterey Institute of International Studies. He is currently working as a Presidential Translator on the Washington-Moscow Hotline. This paper is a result of his regional travels across the Central Asia and research at the George C. Marshall European Center for Security Studies in Garmisch, Germany.
} 
significant operational setbacks, lack of tactical expertise and human rights abuses is not bound to cause a sweeping reformation of the armed forces and security services. At the same time, internalization of the sum of all the operational experiences and lessons learned can be expected to influence national geopolitical choices insofar as prompting a country to seek allies most willing to assist it with meeting its key security and military modernization needs. For players outside the region such as the United States and Europe, a rationale for maintaining the current level of regional engagements in Central Asia becomes an almost Clausewitzian derivative of their broader geopolitical strategies. While far from harboring any "Great Game" type of ambitions, continued Western involvement in Central Asia, including in the realm of security cooperation, helps the West gain additional avenues of cooperation with China, possess at least moderate influence over Russian ambitions in the latter's "near abroad" and, in the case of robust security cooperation with Tajikistan, secure a potential engagement opportunity with Iran.

\section{Regional Threats and Challenges}

As identified by contemporary Uzbek political expert Shavkat Arifhanov, at a broad regional level all Central Asian states look at their military and security structures in the context of the following threats and concerns: border security focused on post-ISAF Afghanistan and prevention of the flow of terrorists, narcotics and weapons from Afghanistan into the region (as a source of instability, post-ISAF Afghanistan has the least relevance for Kazakhstan); containing the threat of homegrown and externally-supported religious extremists; preventing escalation of interregional tensions in the potential "conflict zone" of the Fergana valley (for Uzbekistan, Tajikistan and Kyrgyzstan) and responding to domestic, social and ethnic unrest caused by increasing unemployment and deteriorating living conditions. ${ }^{1}$

\section{Kazakhstan}

The latest of four military doctrines issued since 1993, Kazakhstan's military doctrine of 2011 reflects the security priorities of a country that does not believe a change of the security situation in Afghanistan after 2014 will necessarily have a significant impact on Kazakhstan and is more concerned with internal security issues. ${ }^{2}$ By making only one contextual reference to the persistent instability in Afghanistan as one of the multiple preconditions to the wider regional aggravation, the military doctrine reveals Kazakh security establishment's belief that its central Asian neighbors will serve as buffer states likely to absorb the brunt of the instability generated from within Afghanistan. While the doctrine mentions the military conflicts close to Kazakhstan's borders as one of its six key external concerns, it does not explicitly identify Afghanistan as a threat. The prevalence of the non-Afghanistan focused security concerns is further outlined in the IHS

1 Shavkat Arifhanov, Centralinaya Azia: Nastoiaeshee i Budushee (Central Asia: Present and Future) (Tashkent: Extremum Press, 2010), 143.

2 "Voennaia Doktrina Respubliki Kazakhstan," 2011, available at http://www.nomad.su/?a=3201111010034 , accessed 15 November 2013. 
Jane's Sentinel Security Assessment on Kazakhstan which points out that "Kazakhstan faces a lesser threat from radical Islamist militants than other Central Asian states, although it is concerned about the growth of fundamentalist groups and suffered its first suicide bombing in May 2011 which acted as a precursor to several other attacks." 3

Despite the fact that the Kazakh Armed Forces remain numerically second to Uzbekistan and, according to IHS Jane's assessment, are underfunded, ill-equipped and poorly trained, they have emerged as the most technologically advanced forces in Central Asia. ${ }^{4}$ Kazakhstan's security concerns and aspirations highlight its status as the most developed and internationally open country in Central Asia and one that is attempting to slowly modernize its forces while striking a precarious balance of security cooperation between the West, Russia and China. Over the last fifteen years, Kazakhstan has also emerged as the most advanced peacekeeping force within the region. As per The Military Balance, "About 20,000 serve in the army, 12,000 in the air force and 3,000 in the navy. There are about 4,000 special forces, 9,000 border guards, 20,000 Internal Security (police) troops and 2,500 presidential and government guards." 5

Specifically, its military doctrine identifies six external military security threats and three domestic military threats. Kazakh security officials find

Socio-political instability in the region as a key external security concern followed by
military conflict close to the country's borders, use of foreign nations or organizations
of military political pressure and advanced information-psychological warfare tech-
nologies to meddle in Kazakhstan's internal affairs, increase influence of military po-
litical organizations and unions to the detriment of the state's security service, threat of
terrorism and dangers posed by use and proliferation of weapons of mass destruction.
Domestic threats include: extremist, nationalist and separatist movements... seeking to
destabilize the domestic situation ... illegal armed groups and illegal proliferation of
weapons, munitions and explosives that could be used for sabotage, terrorist acts or
other illegal actions.

The country's security experts and officials question the gravity of a potential "bleed out" effect from Afghanistan and feel sufficiently geographically separated from Afghanistan to not gear the country's armed forces for an ultimate confrontation with the Taliban. ${ }^{7}$ Instead, the country's military establishment focuses its efforts on the modernization of its armed forces and preparing to contain internal threats while also developing a partnership and peacekeeping capacity. Realizing that large conscript-staffed motorized units have low training and readiness levels, the Kazakhstan Ministry of

Security, Kazakhstan (London: IHS Global Limited, 2012).

Kazakhstan at a Glance. Executive Summary (London: HIS Global Limited, 2012).

5 "Chapter Five: Russia and Eurasia," The Military Balance 113, no. 1 (February 2013): 199244.

6 Roger McDermott, Central Asian security post-2014. Perspectives in Kazakhstan and Uzbekistan (Copenhagen: Danish Institute for International Studies, 2013), available at http://subweb.diis.dk/graphics/Publications/Reports2013/RP2013-12-McDermott-Kazakhstan_web.jpg.pdf (30 November 2013).

7

Ibid. 
Defense has chosen to concentrate on developing special operations and airborne units. ${ }^{8}$ In April 2010, Kazakhstan responded to revolution and instability in Kyrgyzstan by relocating air, infantry, police and border protection assets to Taraz in the southern region of Jambyl. .' Additionally, as per Jim Nichol's Congressional Research Service assessment, "The Zhanaozen violence of December 2011 may have spurred military procurement of added airlift capabilities and redeployment of some troops to Southwestern Kazakhstan." 10 On the issue of reforms, the same assessment states: "Reforms include the transition to a brigade-based organizational and staff structure, the creation of the Cadet Corps School for NCOs, and other elements of a hierarchy of military educational institutions." 11

Kazakhstan continues to pursue a multi-vector foreign policy and remains an active participant in the Collective Security Treaty Organization (CSTO) and Shanghai Cooperation Organization (SCO), a reality underlined by the fact that Russia and China are Kazakhstan's main trading partners. Over the last twenty years, Russia has trained thousands of Kazakh officers and has been given the status of a preferential military procurement partner. As noted in IHS Jane's country assessment, "The 'special relationship' with Russia should allow the Kazakh military to gradually increase its procurement efforts by taking advantage of direct arms transfers and Russia's low domestic prices."12

Moreover, the country plays a major role in the CSTO and has participated in all CSTO military exercises, such as "Cooperation 2012" and "Shyghys 2011" as well as the bi-lateral Russian-Kazakh "Tsentr" series of exercises. At the same time, although Astana is the most active Central Asian participant in the CSTO and assigned its best equipped brigade, the $37^{\text {th }}$ Air-Assault Brigade, to the CSTO Collective Rapid Reaction Forces, Kazakhstan has attempted to avoid over-reliance on Russia or the CSTO as its sole military cooperation partner and venue, respectively. ${ }^{13}$

Kazakhstan's military leadership dedicated a BDE minus (KAZBRIG) as a unit devoted to the specific purpose of contributing to future peacekeeping missions. IHS Jane's assessment states that

Achieving full NATO interoperability for KAZBRIG remains a goal in Kazakhstan's NATO's Individual Partnership Action Plan (IPAP). A company from the KAZBRIG was deployed as part of the US-led coalition forces in the early days of the Iraq war, performing de-mining and water purification duties with a Polish-led division. ${ }^{14}$

8 World Armies - Kazakhstan (London: IHS Global Unlimited, 2013).

9 Ibid.

10 Jim Nichol, Kazakhstan: Recent Developments and U.S. Interests (Washington DC: Congressional Research Service, 2013), 20, available at http://www.fas.org/sgp/crs/row/97-1058.pdf (1 December 2013).

11 Ibid.

12 Procurement, Kazakhstan (London: IHS Global Unlimited, 2013).

13 Kazakhstan Armed Forces (London: IHS Global Limited, 2013).

14 World Armies - Kazakhstan. 
Further, Kazakhstan has actively cooperated with NATO through its Partnership for Peace (PfP) program and has continuously hosted the multilateral annual NATO-led exercise, "Steppe Eagle." However, Kazakhstan has been careful not to get too close to the U.S. and NATO, lest it unduly irritate Russia. In these terms, Kazakhstan's decision not to host "Steppe Eagle" in 2014 might conveniently serve a dual purpose by, firstly, indicating the Kazakh military's intent to conduct a larger scale training exercise at the NATO training grounds in Hohenfels, Germany and, secondly, allowing the country to maintain a balance of its partnership between both Russia and NATO.

The country's overall economic stability, hydrocarbon wealth and successful recovery from the 2008 financial crisis translated into the Kazakh military's ability to buy equipment with its own money, form several joint ventures with foreign defense companies and bode well for the future of the military to military cooperation. According to The Military Balance, Astana spent 0.9 percent of GDP, or USD 2.27 billion, on defense in 2012 and plans for a 13 percent increase in defense spending in 2014 (around USD 2.4 billion). ${ }^{15}$ While the Russians also believe that Kazakhstan has been spending considerable amounts on defense, their estimate of Kazakhstan's 2012 defense expenditures is lower, at about USD 1.3 billion. ${ }^{16}$

Increased defense spending is in line with President Nazarbaev's intent to have up to 70 percent of its weapons and military equipment manufactured domestically by $2015 .{ }^{17}$ Kazakhstan has been actively diversifying its supply of weapons systems and therefore signed agreements with France, Turkey, Italy, Poland, Spain, Ukraine and Israel. ${ }^{18}$ In October 2013, IHS Jane's Defence Weekly reported that Kazakhstan had ordered two new Airbus Military C295 tactical transport aircraft in addition to the two delivered earlier this year. ${ }^{19}$ According to an Oxford Analytica report, between 2013 and 2017 Kazakhstan also plans to spend over 1.3 billion dollars on purchasing unspecified high-tech security equipment and training of law-enforcement officers. ${ }^{20}$ Kazakhstan has also launched a program to boost its nascent naval capabilities, unveiling it first domestically

15 "Kazakhstan to Spend More on Defense and Disaster Prevention," BNews.kz, 11 September 2013, available at http://bnews.kz/en/news/post/158111/ (15 December 2013).

16 Murat Beyshenov, "The Armed Forces of Kyrgyzstan: Brief Overview and Perspectives for Development at the Current Stage," in Almanac 2012: Governing and Reforming Kyrgyzstan Security Sector, ed. Aida Alymbaeva, tr. Greta Kerimidchieva (Geneva-Bishkek: Geneva Centre of the Democratic Control of the Armed Forces, 2013), 26, available at www.dcaf.ch/Publications/Almanac-on-Security-Sector-Reform-in-the-Kyrgyz-Republic $\quad$ (10 December 2013).

17 "Chapter Five: Russia and Eurasia," The Military Balance, 113, no. 1 (February 2013): 199244.

18 Ibid.

19 Gareth Jennings, "Kazakhstan Signs for Additional C295 Transport Aircraft," Jane's Defence Weekly, 24 October 2013.

20 “Kazakh Security Measures Address Emerging Threats," Oxford Analytica Daily Brief, 12 August 2013. 
built patrol vessel in 2012 and signing agreements with French and Spanish firms to produce Exocet-class anti-ship missiles. ${ }^{21}$

Current cooperation with the U.S. is based on the following three pillars: preparing the KAZBRIG Brigade for eventual UN deployment, achieving moderate change within the military education structure through IMET (about twenty Kazakh students attend various military schools in the U.S.) and cooperation in the military intelligence sphere. Most recently, the Kazakh Army has also been placing more emphasis on NCO development.

Overall, compared to other Central Asian states, Kazakhstan has invested the most into modernizing its armed forces. Its multi-vector foreign policy has allowed the country to maintain good relations with all of its international partners and benefit from cooperation with each one of them. Given its wealth and ability to purchase and manufacture military equipment, Kazakhstan sees itself as a willingly-contributing coalition partner not interested in security assistance handouts from other countries. ${ }^{22}$ While Russia predictably enjoys an enduring "special relationship" with Kazakhstan, the U.S. and other foreign partners are likely to continue playing important roles in shaping the Kazakh military. There is no reason to believe that the Kazakh Armed Forces are incapable of effectively handling an internal security issue or responding to a socio-political crisis in the neighborhood or on its southern border. At the same time, the post-Soviet military legacy of insufficiently trained, largely conscripted units remains hard to overcome, leading to a division within the armed forces. The existence of better-trained elite airborne and special operations units stands in sharp contrast with the rest of the conscriptmanned conventional motorized and armored units.

\section{Kyrgyzstan}

In contrast to Kazakhstan, the July 2013 Kyrgyzstan military doctrine emphasizes the importance of the situation in Afghanistan and ISAF withdrawal, making it a key national security risk. ${ }^{23}$ The concept links it to a potential deterioration of the security environment in Central Asia and Kyrgyzstan in particular, while also connecting it with a variety of external threats, such as an expansion of terrorism, religious extremism and drug trafficking (along the so-called "northern route" through Central Asia). In this context, the concept stresses the criticality of ties with the CSTO as a guarantor of regional peace and stability (Bishkek hosts the headquarters of the CSTO's rapid reaction force). ${ }^{24}$ Concurrently, Kyrgyzstan must balance the interests of the U.S., Russia and

21 Procurement, Kazakhstan.

22 Ibid.

23 "Voennaia Doktrina Kyrgyzskoi Respubliki (Military Doctrine of the Kyrgyz Republic) 2012," 24 available at http://www.centrasia.ru/newsA.php?st=1374474180 (21 June 2014). Ibid. 
China as key players influencing Central Asia. ${ }^{25}$ When it comes to internal issues as they concern security, the concept stresses inter-ethnic stability and separatism, borderdelineation, water and energy tensions as well as high potential for instability in the Fergana valley.

The 2012 defense budget estimates vary considerably from USD 111 million, according to Russia, to about USD 105 million from The Military Balance quoted in IISS, to about USD 246 million, according to IHS Jane's budget analysts. ${ }^{26}$ As per The Military Balance,

Kyrgyzstan's armed forces number about 10,900 active ground and air force troops. Paramilitary forces include 5000 border guards, 3,500 police troops and 1,000 National Guard troops... The small air force (2,400 personnel) consists of 33 aircraft and 10 helicopters based at Kant. ${ }^{27}$

Regardless of the actual defense spending figure, according to an interview given by Kyrgyzstan's defense minister Taalaybek Omuraliyev to Radio Free Europe/Radio Liberty's Kyrgyz service, the armed forces have been receiving only half of what they have been requesting from the government. ${ }^{28}$ According to IHS Jane's, "The Kyrgyz military remains an embryonic force with a weak chain of command, the ground force built to Cold War standards, and an almost total lack of air capabilities." ${ }^{29}$ The Kyrgyz military's most recent operational experience entailed a disastrous deployment of army units to quell ethnic unrest in Jalalabad and Osh in June 2010. Deep-seated tensions between the Uzbek and Kyrgyz communities in the southern cities of Jalalabad and Osh manifested in street violence on June 10-13, 2010. About 470 people (mostly ethnic Uzbeks) were killed in violent clashes, 3,000 primarily Uzbek businesses were destroyed and more than 100,000 refugees temporarily left their homes.

As per the aforementioned assessment, "During the initial phase of military deployment in southern Kyrgyzstan, troops from the Ministry of Defense seemed prepared for an act of aggression committed by Uzbekistan..."30 Kyrgyzstan's military leaders cited a lack of trained personnel, equipment and funding as well as a general inability to control the situation as main reasons for their inability to rein in the violence in the first two days. The army was so ill-equipped to respond to domestic insurgency that it had to "borrow armored vehicles from fellow CSTO states in order to respond to the situa-

25 Jim Nichol, Kyrgyzstan: Recent Developments and U.S. Interests (Washington DC: Congressional Research Service, 2013), available at www.fas.org/sgp/crs/row/97-690.pdf (25 October 2013).

26 Alymbaeva, Almanac 2012: Governing and Reforming Kyrgyzstan Security Sector, 26; "Chapter Five: Russia and Eurasia," 199-244; and email to the author from IHS Jane's defense budgets analyst.

27 Nichol, Kyrgyzstan: Recent Developments and U.S. Interests.

28 "Interview with Kyrgyz Minister of Defense Taalaybek Omuraliev," Radio Azzatyk, 23 September 2013, available at http://rus.azattyk.org/content/kyrgyzstan_defence_ministry/251145 25.html (12 December 2013).

29 Armed Forces, Kyrgyzstan (London: IHS Global Limited, 2013).

30 Ibid. 
tion. ${ }^{31}$ The army and police units showed complete ineptitude and a lack of tactical prowess, "acting chaotically, often reacting to rumors spread by provocateurs." ${ }^{32}$ The inability of the domestic security forces to deal with inter-ethnic strife effectively was punctuated by then Acting President Roza Otunbayeva's call to Russia for the deployment of CSTO troops (the CSTO never agreed to send troops and only sent humanitarian assistance).

The poor performance of army and police units in Jalalabad and Osh provided additional impetus for the Kyrgyz military leadership to continue reforming the armed forces in order to develop a compact, mobile force able to effectively respond to internal unrest and serve as a deterrent to Islamic militants and drug traffickers crossing the Kyrgyz-Tajik border. The majority of efforts have been directed towards creating company-sized special operations detachments specializing in mountain and counter-insurgency warfare. ${ }^{33}$ The most capable 3rd Special Operations Battalion is considered the best-trained and best-equipped unit in the military. ${ }^{34}$ An absence of adequate airlift and air support capabilities is compensated by reliance on the Russian capabilities that would be employed in case of an emergency operation. Russia's decision to double the number of airplanes on its military airbase in Kant outside of Bishkek by the end of 2013 is a clear indication of its dominance over all Kyrgyz military matters of strategic importance, especially if viewed against the backdrop of the pending closure of the Manas Transit Center. ${ }^{35}$ Overall, fighting alongside Russian forces, possibly within the CSTO (Kyrgyzstan participates in all CSTO exercises), appears to be a linchpin of the Kyrgyz defense strategy. A continuous lack of domestic funding requires absolute dependence on military aid from donors, primarily Russia, which, according to a source in the Russian General Staff, has reportedly agreed to provide Kyrgyzstan with

... helicopters, armored personnel carriers and armored automobiles, multiple rocket launcher systems 9K57 Uragan (Kyrgyz armed forces have only six such systems now), artillery systems, small arms, as well as communication and reconnaissance means. ${ }^{36}$

In 2008, the Defense Minister of Kyrgyzstan remarked that about 90 percent of the Kyrgyz army's foreign-trained officers were educated in Russia. ${ }^{37}$

31 Ibid.

31 Ibid.

32 Armed Forces, Kyrgyzstan (London: IHS Global Limited, 2013).

33 Ibid.

34 "Official: Russia to Expand Kyrgyzstan Military Airbase," Defence News, 27 October 2013, available at www.defensenews.com/article/20131027/DEFREG03/310270006 (3 November 2013).

35 Ivan Safronov, Elena Chernenko and Kabai Karabekov, "Russia Will Arm Kyrgyzstan and Tajikistan," Kommersant Online, 2 October 2013, available at http://www.ebiblioteka.ru/ browse/doc/36159922 (5 November 2013).

36 Sebastien Peyrouse, "Russia-Central Asia: Advances and Shortcomings of the Military Partnership," in Central Asian Security Trends: Views from Europe and Russia., ed. Stephen J. Blank (Carlisle, PA: Strategic Studies Institute, U.S. Army War College, 2011), 1-34. 
Meanwhile, although the scale of contribution by other Kyrgyz partners is far less significant, the country's military leadership is eager to accept aid from any partner. As pointed out by current Defense Minister Taalaybek Omuraliev, low defense spending makes international military cooperation paramount to building Kyrgyzstan's armed forces capacity. ${ }^{38}$ In these terms, Kyrgyzstan's cooperation with NATO remains an important dimension of its military modernization strategy. As pointed out in the 2013 working paper released by the EUCAM-Security and Development project,

\begin{abstract}
So far, Kyrgyzstan's practical cooperation with NATO has been guided by the country's annual Individual Partnership Cooperation Programme (IPCP), which includes security and peacekeeping, counter-terrorism, border security and crisis management. In 2007, Bishkek also joined the PfP Planning and Review Process (PARP)... Under this framework, NATO has provided military language training, search and rescue education, border security and human rights courses along with the re-training of released military personnel. ${ }^{39}$
\end{abstract}

On the bilateral level, over the last decade the U.S provided different small-scale training and equipment to Kyrgyz Special Forces units. However, the future volume of military-to-military cooperation is likely to diminish, as the U.S. will be hard pressed to justify providing aid at current levels after the closure of the Manas Transit Center in July 2014.

Turkey, China and India also emerged as minor contributors to Kyrgyz defense, having provided or committed to providing various types of assistance. For instance, over the last fifteen years, India has trained 26 Kyrgyz military students, while according to the January 2012 military cooperation agreement between Turkey and Kyrgyzstan, Turkey will help "build a military institute in Osh and build up the country's defense industry." 40

A brief assessment of the armed forces' response to ethnic violence in June 2010 in southern Kyrgyzstan, combined with the grave difficulties facing the Kyrgyz armed forces along the lengthy path to modernization, make Russia and the CSTO natural security guarantors. If left to its own devices the Kyrgyz military will likely struggle again to adapt and meet its doctrinal objectives. Even quelling limited-scale civil or ethnic unrest might present a great challenge to the Kyrgyz military. As one of the weakest armed forces in Central Asia, the Kyrgyz military will undoubtedly require Russian/CSTO assistance in order to effectively expel a terrorist incursion or respond to wide-scale border instability. At this juncture no other state, rightfully in the author's view, is willing to compete with Russia for influence over Kyrgyzstan. In this context, the closure of Ma-

37 "Interview with Kyrgyz Minister of Defense Taalaybek Omuraliev."

38 Jos Boonstra, Erica Marat and Vera Axynova, Security Sector Reform in Kazakhstan, Kyrgyzstan and Tajikistan: What Role for Europe? (EUCAM, 2013), available at http://www.fride.org/download/EUCAM_WP14_SSR_Kazakhstan_Kyrgyzstan_Tajikistan.pdf (8 December 2013).

39 Joshua Kucera, “Turkey Promises to Boost Military Aid to Kyrgyzstan,” Eurasianet.org, 19 January 2012, available at http://www.eurasianet.org/node/64866 (10 November 2013). 
nas signifies an inevitable and justified decrease in American willingness to expend efforts on the failing military of a Russian "client state."

\section{Tajikistan}

As stated in the 2007 volume on Defense and Security Sector Institution Building in Central Asia published by the Geneva Centre for the Democratic Control of Armed Forces (DCAF), in 2006 Tajikistan was the last Central Asian state to adopt a military doctrine. $^{41}$ As the poorest nation in Central Asia and the only country of the former Soviet Union to have experienced a devastating Civil War, Tajikistan struggled a decade longer than its neighbors with establishing a legal basis for military control and planning and with formulating a coherent military strategy.

The Tajik security concept is reinforced by the current political rhetoric and outlines the Tajik foreign and domestic interests. ${ }^{42}$ Specifically, the Tajik Armed Forces and Security Services are charged with protecting state borders and repelling any internal and external aggression, preserving territorial integrity and resolving conditions leading to political, religious and ethnic separatism. Additionally, they must also deal with transnational organized crime activities. In Central Asia Post-2014, Roger McDermott notes:

The security document outlines the main threats to the country and pays almost no attention to Afghanistan. Security thinking in Dushanbe places very little emphasis on terrorism or inter-state conflict, and more on drug trafficking, organized crime or separatism - in other words the indirect impact of Afghanistan-related transnational threats. $^{43}$

Tajikistan is an original member of the Shanghai Cooperation Organization (SCO) and belongs to the CSTO. Tajikistan also joined NATO's PfP in 2002.

According to The Military Balance, the Tajik government allocated approximately USD 164 million, or about 1.5 percent of its GDP to defense in 2012. ${ }^{44}$ IHS Jane's Defense Budget analysts provide a similar figure of USD 169.4 million for the same year, noting that the actual spending might in fact have been different as no revised estimates have been published since 2011. Additionally, the Tajik defense budget "has more than doubled in nominal terms over the past five years" from USD 69 million in 2008 to

${ }^{40}$ Eden Cole and Philip Fluri, eds., Defence and Security Sector Institution Building in the PostSoviet Central Asian States (Geneva: Geneva Centre for the Democratic Control of Armed Forces, 2007), available at http://www.dcaf.ch/Publications/Defence-and-Security-SectorInstitution-Building-in-the-Post-Soviet-Central-Asian-States (1 December 2013).

41 Arifhanov, Centralinaya Azia: Nastoiaeshee i Budushee (Central Asia Present and Future) and Jim Nichol, Tajikistan: Recent Developments and US Interests.

42 Roger McDermott, Central Asian security post-2014. Perspectives in Kazakhstan and Uzbekistan (Copenhagen: Danish Institute for International Studies, 2013), available at http://subweb.diis.dk/graphics/Publications/Reports2013/RP2013-12-McDermott-Kazakhstan_web.jpg.pdf (20 December 2013).

43 "Chapter Five: Russia and Eurasia," The Military Balance (February 2013). 
USD 169.4 million in $2013 .^{45}$ In sharp contrast, the Center for Military and Strategic Studies of the General Staff of the Armed Forces of the Russian Federation provides a low figure of just USD 20 million for the same year. ${ }^{46}$

The Tajik military continues to be plagued by a lack of funding and resources. ${ }^{47}$ Standing at about ten to thirty thousand men, depending on the estimate, and consisting of ground, air force, air defense and newly-established mobile rapid reaction forces, the Tajik military and security forces still employ a conscript system and have had difficulties responding rapidly and effectively to domestic security challenges. ${ }^{48}$ As demonstrated by the 2010 counterinsurgency (COIN) operation in the Rasht Valley and the summer 2012 operation in Khorog, even in the domestic operating environment, the Tajik military has faced difficulties in conducting successful COIN operations. Both operations demonstrated the government's willingness to squash any internal insurrection, albeit with limited success, and were believed to have been conducted without proper regard for human rights. ${ }^{49}$

A detailed look at the 2012 Khorog operation highlights the current challenges facing the Tajik Armed Forces and Security Services tasked with quelling domestic unrest. In response to the killing of a national security official, General Abdullo Nazarov, the government dispatched about 3,000 security personnel to the Gorniy Badakhshan Autonomous Oblast in southeastern Tajikistan. On July 24, 2012, the government forces entered the capital of the Khorog region and fought groups of insurgents around the town's bread factory. The majority of experts agree that despite a relatively short fighting phase of the operation, which lasted less than 24 hours, the government forces were slow to react, showed complete incompetence in executing basic maneuver tasks and were forced to quickly seek a truce with their opponents. Given the distance between Khorog and Dushanbe (approximately $600 \mathrm{~km}$ over partially paved mountain roads) as well as an effective early-warning system employed by Pamiris, the operation was doomed. It did not achieve the element of surprise and resulted in numerous casualties on both sides. Unofficial accounts put the number of deaths at about twenty people on behalf of Pamiris and about as many, if not more, on the side of the government forces. The actions of the Tajik forces during both operations, specifically the units' inability to effectively call for fire, render timely first aid and execute command and control, underline the Tajik government's need to modernize its military and compel it to rely on CSTO forces (201st IN DIV) in the case of a wide-scale coordinated internal or external attack. The Russian 201st IN DIV (approximately 6,000 soldiers) occupies three bases in Tajikistan and is the largest Russian force outside of Russia. Russian troops serve to ensure the Tajik regime's survival in case of a national emergency and protect Russian regional

44 Email to the author from IHS Jane's Defense Budgets analyst.

45 Alymbaeva, Almanac 2012: Governing and Reforming Kyrgyzstan Security Sector, 26.

46 Tajikistan at a Glance (London: IHS Global Limited, 2011).

47 Ibid. and "Chapter Five: Russia and Eurasia," 199-244.

48 This assessment is based on conversations with several U.S. officials and local observers during the author's visit to Khorog in the Summer of 2013. 
interests. $^{50}$ As a core CSTO force in Central Asia, the 201st IN DIV will likely play a larger role in defending Tajikistan following the ISAF withdrawal from Afghanistan in 2014.

Tajikistan's heavy dependence on remittances from migrant workers in Russia, the government's realization of the shortcomings of its forces and perpetual concern about the destabilizing influence of a weak and unstable post-ISAF Afghanistan are all significant reasons why the country's leadership has sought a stronger security alliance with Russia within the CSTO. Additionally, as noted by Sebastien Peyrose in his article on Russian military cooperation with Central Asia, "For Moscow, the security of the southern borders of Central Asia is seen as a question of domestic security." In light of Moscow's renewed drive to increase influence over Central Asia and Dushanbe's recent extension of the basing agreement for the 201st IN DIV, as well as a possible basing of Russian military-transport aircraft on the recently Indian-renovated Ayni airbase, Russia pledged USD 200 million towards modernizing the Tajik military. ${ }^{52}$ In September and October 2013, the CSTO's Secretary General Nikolay Bordyuzha and Russia's Chief of the General Staff Valery Gerasimov confirmed that both Kyrgyzstan and Tajikistan would be receiving various types of heavy military equipment in 2013-2014. ${ }^{53}$ However, the fulfillment of this pledge is highly questionable. According to an article in the Russian Nezavisimoe Voennoe Obozrenie in October, Russia's military industrial complex has thus far struggled with re-arming the CSTO militaries with new weaponry and is unlikely to promptly provide the promised equipment. ${ }^{54}$

While the U.S. has never had any bases in Tajikistan, it is helping the Tajik government prepare a battalion for eventual peacekeeping deployment and, in the process, professionalize the Tajik armed forces. In support of this initiative, the U.S. Office of Military Cooperation has directed Tajikistan's State Partnership Program training partner, the Virginia National Guard, to concentrate on teaching a designated Tajik peacekeeping unit first aid, operations in mountainous terrain, call for fire and basic surveillance/ recon techniques. Tajikistan's defense ministry intends to host the next iteration of the main NATO PfP exercise, "Mountain Eagle" (previously known as Kazakh-led "Steppe Eagle"), in Tajikistan in the fall of 2014 reflects Tajikistan's attempts to increase the

49 Gregory Gleason, "Why Russia is in Tajikistan," Comparative Strategy, 20, no. 1 (2001): 7788.

50 Dmitriy Trenin, Sebastien Peyrouse, "Central Asian Security Trends: Views from Europe and Russia," in Russia-Central Asia: Advances and Shortcomings of the Military Partnership, ed. Stephen J. Blank (Carlisle, PA: Strategic Studies Institute, U.S. Army War College, 2011), 134.

51 "Central Asia's Military Shifts Strengthen Russian Ties," The Oxford Analytica Daily Brief, 15 August 2013.

52 "Base Agreement Will Boost Russia-Tajikistan Relations," The Oxford Analytica Daily Brief, 9 October 2013.

53 Vladimir Mukhin, “Ochen’ Dorogaia Kollektivnaia Oborona (Very Expensive Collective Defense)," Nezavisimoe Voennoe Obozrenie, 23 October 2013, available at www.ng.ru/armies/ 2013-10-23/1_oborona.html. 
readiness of its forces and willingness to further deepen its relationship with the U.S. in the security sphere.

The readiness and ability of the Tajik border guards to repel an organized terrorist attack from the south of the border is another cause of regional concern. Since 2005, Tajik border guards have been patrolling the Afghan border without the help of their Russian counterparts. Although the current manning of an average checkpoint, normally a platoon plus size element (about fifty personnel), deters small groups of terrorists and narcotraffickers from seeking confrontations with the border guards, it is unlikely to stop a coordinated insurgent attack with heavy weapons. Also, a lack of transportation questions the border guards' ability to prevent illegal border crossings. The issue of inadequate border security has not been lost on Russia, the U.S., China and India. All four states have tried to play a role in defending Tajikistan's southern borders.

Over the last ten years, under the auspices of its counter-narcotics program, the U.S. has transferred multiple vehicles, radios and supplies to the Tajik border guards. Currently, all border checkpoints have a functional means of communication with their regional headquarters and troops at some checkpoints capable of patrolling the border using U.S.-provided vehicles.

Apart from Russia and the U.S., India and China are two further states that play an active role in shaping the Tajik armed forces. Many young Tajik officers have had a chance to attend Indian defense colleges in order to learn English and Western military methodology. Additionally, India is in the process of giving Tajikistan two MI-17 transport helicopters and is finishing construction of a military hospital in Farkhor, southern Tajikistan. India has also renovated the aforementioned Ayni airbase. China's exact involvement in the defense sector is less clear. As of mid-2013, the Chinese have been constructing an operational center for the Tajik defense ministry in Dushanbe and inviting several Tajik officers to study in Chinese defense colleges.

A review of the current Tajik military capabilities concludes that, although in their current configuration the Tajik armed forces may be able to successfully quell another geographically isolated domestic insurgency such as Garm in 2010 or Khorog in 2012, the Tajik army and border guards would likely struggle to independently contain a widescale internal insurrection or stop a well-trained group of terrorists attempting to infiltrate the southern border of Tajikistan.

\section{Turkmenistan}

Of all the Central Asian states, Turkmenistan has always been the least engaged in international security cooperation, sticking to its long-standing doctrine of positive neutrality. Turkmenistan is not a part of the CSTO or the SCO and enjoys only an unofficial associate membership in the CIS. However, since assuming control of Turkmenistan in 2006, President Gurbanguly Berdymukhamedov made some moderate efforts to become more active in the economic sphere and shift away from a strategy of international isolationism of the previous years. According to information provided in The Military Balance and used by Jim Nichol in his CRS report, 
Turkmenistan's armed forces number about 22,000, including 18,500 ground, 3,000 air, and about 500 naval/coast guard forces. The army has about 700 tanks, 2,000 vehicles, and 560 artillery pieces, the air force has about 110 aircraft and helicopters, and the naval force has six patrol boats (including a former U.S. Coast Guard vessel). During 2011, Turkmenistan purchased four missile boats from Russia and Turkey, and the Russian boats reportedly have been delivered. ${ }^{55}$

As per Turkmenistan's January 2009 military doctrine outlined in IHS Jane's assessment, "the principal function of the armed forces is to repel external aggression. This is split into two missions: to protect the Caspian littoral and ensure that borders with Afghanistan and Iran are as robust as possible." role for the armed forces in responding to domestic instability and does not allow for any foreign bases to be established in the country. The ground forces are neither tasked nor equipped to project power beyond the country's borders. IHS Jane's assessment considers Turkmenistan's armed forces "among the weakest in the Central Asian region." 57 Defense spending is considered among the lowest in the region, estimated to be between USD 210 to USD 250 million in 2011, or about 0.5 percent of GDP (government budget figures are not public knowledge and there is a total dearth of information when it comes to all aspects of public spending). ${ }^{58}$ Turkmenistan's military has had no operational experience since achieving independence and remains tactically weak and incapable. However, the Turkmen armed forces' overall lack of experience is mitigated by the fact that the threat of religious extremism and terrorism in Turkmenistan remains the lowest in the region. ${ }^{59}$ Over the last five years, there have been no reported terrorist acts across the country.

As the majority of security issues facing the country are maritime and concentrated around dividing the Caspian energy-rich sea shelf between Turkmenistan, Azerbaijan and Iran, Turkmenistan's navy has been given considerably more attention than its air and land forces. Over the last three years Turkmenistan reinforced its Caspian naval capabilities by procuring several Russian and Turkish corvettes and patrol boats. When it comes to its ground forces, the situation differs greatly. The president's 2008 announcement about Turkmenistan's willingness to potentially participate in international peacekeeping activities appeared to be empty rhetoric and has not affected military planning. ${ }^{60}$

54 Jim Nichol, Turkmenistan: Recent Developments and U.S. Interests (Washington DC: Congressional Research Service, 2012), available at http://www.fas.org/sgp/crs/row/97-1055.pdf (15 January 2014).

55 Turkmenistan Armed Forces (London: IHS Global Limited, 2013).

56 Turkmenistan Executive Summary (London: IHS Global Limited, 2012).

57 "Chapter Five: Russia and Eurasia", 199-244; and Turkmenistan Defence Budget (London, UK: IHS Global Limited, 2012).

58 Many experts note that the absence of radicalism is largely due to the fact that a uniquely Turkmen brand of Islam is not particularly prone to radicalization. Additionally, the local 59 security services closely monitor the society for any signs of dissatisfaction.

Ibid. 
Although over the last four years Turkmenistan has purchased 40 Russian-made T-90S main battle tanks and Pechora-2M air defense missile systems, a general lack of training and operational experience paired with abstention from participation in any regional exercises have left the country's ground forces largely incapable of effectively responding to a conventional military threat, envisaged by its own doctrine. ${ }^{61}$

\section{Uzbekistan}

In 2000 Uzbekistan adopted its latest security doctrine that still remains the cornerstone of its defense strategy. Along with the strategy for development of the armed forces updated in 2012, these documents outline Uzbekistan's national defense priorities. ${ }^{62}$ Specifically, as noted in Eden Cole's work, the 2000 doctrine "classifies possible conflicts into small and middle range." The doctrine also identifies terrorism and religious extremism as key threats to national security but does not specify domestic sources of instability. It takes into account lessons learned during the Tajik civil war and instability in the Fergana Valley. The 2012 document reflects President Islam Karimov's strategy for further development of the armed forces. Specifically, according to IHS Jane's, in January 2012 President Karimov outlined the following priorities for military development: ensure constant combat readiness and increased mobility, upgrade and modernize military material, expand international military-technical cooperation, improve administrative networks and increase levels of professionalism among officers and sergeants. ${ }^{63}$ Uzbekistan maintains a membership in the SCO but suspended its CSTO membership in June 2012. Uzbekistan reaffirmed its participation in NATO's PfP in 2010.

According to information provided in The Military Balance and used by Jim Nichol in his CRS report,

The Uzbek armed forces are the largest in the region in terms of manpower... The armed forces consist of about 24,500 ground force troops, 7,500 air force troops, and 16,000 joint troops. There are also up to 19,000 internal security (police) troops and 1,000 National Guard troops. Uzbekistan spent about $3.1 \%$ (about $\$ 1.4$ billion) of its GDP in 2011 on the defense sector, which would be about $10 \%$ of the budget. ${ }^{64}$

Jane's analysts agree with the defense spending numbers provided by CRS, further noting that spending on defense in 2013 appears to be around only 2.2 percent of GDP. Between 2011 and 2013, as overall government spending increased by 54.7 percent in

60 Aleksei Nikolskiy, “\$500 Million Worth of Tanks," Vedomosti, 14 February 2012, available at http://www.ebiblioteka.ru/browse/doc/26608720 (8 November 2013); and "Turkmenistan Will Not Increase the Air Defense Cooperation with the CIS Countries," RIA Novosti, 11 July 2012, available at http://ebiblioteka.ru/browse/doc/27397091 (2 November 2013).

61 D. Azizov, "Uzbekistan Presents Army Development Strategy," Trend, 14 January 2014, available at http://en.trend.az/regions/casia/uzbekistan/1979892.html (8 January 2014).

62 Uzbekistan at a Glance (London: IHS Global Limited, 2013).

63 Jim Nichol, Uzbekistan: Recent Developments and U.S. Interests, RS21238 (Washington, DC: Congressional Research Service, August 2013), available at http://www.fas.org/sgp/crs/row/ RS21238.pdf (3 January 2014). 
nominal terms, IHS Jane's expects that defense sector growth was similar. ${ }^{65}$ The Russian estimates are in line with IISS and IHS Jane's figures (over USD 1.5 billion in 2012), according to the Center for Military and Strategic Studies of the General Staff of the Armed Forces of the Russian Federation. ${ }^{66}$

Experts agree that, with the exception of Kazakhstan, the Uzbek armed forces are also the second best trained military in the region. According to IHS Jane's assessment, the Uzbek military learned from the 2005 Andijan experience and improved its capabilities to conduct COIN operations: "The army's mobile forces command now controls a number of paramilitary units, including the special operations detachment 'Bars'.,67 Also, since 2005 the Uzbek armed forces have increased their rapid deployment capabilities, with air assault and airborne brigades likely being the units with improved readiness capacity. ${ }^{68}$ While reflecting the absence of an existential threat to the regime, the Uzbek military's attempts to focus on COIN and counter-terror operations are primarily driven by the necessity of reacting to a potential threat from the Islamic Movement of Uzbekistan (IMU) in Northern Afghanistan, face recurring tensions with Tajikistan over Uzbek gas supply, water sharing and border demarcation as well as socio-economic tensions between Uzbeks and Kyrgyz in the Fergana valley. ${ }^{69}$ At the same time, Uzbekistan's suspension of its CSTO membership in June 2012, along with President Karimov's pledge to never deploy Uzbek forces, have limited Uzbekistan's military's exposure to the current operational environment and the country's ability to learn from the experience of other militaries. The SCO exercise, Vostok Anti-Terror 2012, held in the Jizzah region of Uzbekistan in June 2012 and aimed at improving coordination between SCO units in case of a terrorist attack, was the last regional exercise with Uzbek participation. ${ }^{70}$ Uzbekistan only sent observers to the most recent SCO military exercise held in Kazakhstan in June 2013.

Throughout its post-independence history, Uzbekistan has run a nuanced foreign policy, often playing the U.S. against Russia and vice versa. U.S. critique of the Uzbek government crackdown in Andijan in 2005 resulted in deterioration of the U.S.-Uzbekistan relationship and cessation of significant military-to-military cooperation in the mid2000s. President Karimov's 2008 decision to allow the U.S. to transport non-lethal supplies to and from Afghanistan through its territory as part of the Northern Distribution Network (NDN) signaled the latest rapprochement between the two countries. While it remains to be seen how long the current cordial phase of the bilateral U.S.-Uzbekistan relationship lasts, thus far Uzbek cooperation and pledges to keep the NDN going have made it possible to reinstate military-to-military cooperation in the non-lethal sphere.

Following suspension of its CSTO membership in June 2012, Uzbekistan's leadership has taken deliberate steps to ensure the preservation of at least a semblance of a

64 Email to the author from IHS Jane's Defense Budgets analyst.

65 Alymbaeva, Almanac 2012: Governing and Reforming Kyrgyzstan Security Sector, 26.

66 World Armies - Uzbekistan (London: IHS Global Limited, 2013).

67 Uzbekistan at a Glance (London: IHS Global Limited, 2013).

68 Ibid.

69 World Armies - Uzbekistan (London: IHS Global Limited, 2013). 
friendly partnership with Russia. During his visit to Moscow in April 2013, President Karimov highlighted a critical need for bilateral cooperation in the security field, pointing out the eventuality of increased regional instability after the ISAF withdrawal as a reason for enhanced cooperation with Russia. ${ }^{71}$ As pointed out by Roger McDermott, "Karimov wants to deepen an already robust level of intelligence sharing and cooperation with Moscow..."72 However, given the recent history of Uzbek mistrust of any Russian-dominated military alliances, such as the CSTO, any concrete military-to-military cooperation with Russian forces, including joint military exercises, appears unlikely, at least prior to the withdrawal of ISAF forces. Sebastien Peyrose notes that over the last fifteen years, from the Russian standpoint Uzbekistan has been difficult to control. ${ }^{73}$ Extensive security cooperation with Uzbekistan also risks potentially upsetting the Russian relationship with Tajikistan and Kyrgyzstan, its primary Central Asian "client states," which have ongoing border and water sharing disputes with Uzbekistan. ${ }^{74}$

Uzbekistan's leadership's continuous emphasis on military reform and efforts to modernize its forces instills moderate optimism in the country's ability to contain internal insurgency and terrorist threats while also dealing effectively with any instability on its borders. Also, there is no reason to question the government's determination to use troops to put down any internal insurrection, regardless of external criticism, just as it demonstrated in 2005 in Andijan. However, widespread regional instability would likely challenge even the state's ability to effectively protect its borders and would potentially force the regime to look for external help. Although the U.S.-Uzbekistan relationship is on the rise again, the future of the long-term bilateral partnership remains fraught with contention. As the operations tempo in Afghanistan slows down and the amount of cargo transported through the NDN decreases, the U.S. is likely to struggle with justifying providing even non-lethal assistance waivers to Uzbekistan. As previously mentioned, when it comes to the military, Uzbekistan's nuanced foreign policy of maneuvering and picking and choosing its allies has already negatively affected its armed forces and may lead to eventual stagnation within the services.

\section{Internal Conflicts Versus National Security Doctrines}

With the exception of Turkmenistan, all the Central Asian militaries have doctrinal obligations, have had experience with responding to domestic inter-ethnic conflicts or were

70 Dadan Upadhyay, "Russia, Uzbekistan Agree to Join Hands to Meet Afghanistan Threats," Rossiyskaya Gazeta, 2013, available at http://indrus.in/world/2013/04/18/russia_uzbekistan_ agree_to_join_hands_to_meet_afghanistan_threats_23905.html (26 January 2014).

71 Roger McDermott, "Tashkent Strengthens Security Ties with Moscow Ahead of NATO Drawdown," Eurasia Daily Monitor 10, no. 36 (2013), 23 April 2013, available at http://www.jamestown.org/single/?no_cache=1\&tx_ttnews[tt_news]=40772\&tx_ttnews[backP id]=7\&cHash=3f066ae3ba9455daacbcef05128152fe (22 January 2014).

72 Trenin and Peyrouse, "Central Asian Security Trends: Views from Europe and Russia."

73 Alexander Hramchihin, "Slaboe Zveno Centralinoy Azii (The Weak Link of Central Asia)," Nezavisimoe Voennoe Obozrenie, 10 November 2013, available at www.ng.ru/realty/2013-1011/3_odkb.html (12 November 2013). 
involved in quelling civil unrest and instability. Although the degree of success has varied by country, some operational lessons learned apply region-wide and highlight the need for developing similar capacities. While the Kazakh and Uzbek militaries have shown some capacity to contain internal or external crisis on their own (albeit brutally and in a repressive fashion), Tajikistan and Kyrgyzstan have struggled to respond to their respective internal challenges and inevitably sought increased cooperation with Russia and the CSTO. Turkmenistan has remained outside of all regional alliances, its military remaining a mostly obsolete force with no tactical expertise.

Kazakhstan's hydrocarbon wealth has allowed it to initiate an ambitious rearmament and modernization program while achieving moderate changes across its armed forces and further developing its most regionally advanced peacekeeping capacity. An eventuality of instability spreading to Kazakhstan from a neighboring country (2010 events in Kyrgyzstan could have potentially caused unrest in Kazakhstan), as well as a need to respond to an incident of domestic civil unrest similar to Zhanozen in December 2011, led to the regional realignment of forces as well as an additional focus on developing airlift, airborne and special forces capabilities. Despite huge discrepancies between elite airmobile forces and regular units, Kazakhstan's armed and security services appear somewhat better trained, and definitely better equipped, than its neighbors to handle internal unrest or a crisis on its borders. Internationally, Kazakh multi-vector foreign policy has afforded the country the maintenance of robust security cooperation with all of its foreign partners.

Faced with continuous political instability, the turmoil of two revolutions and interethnic strife in 2010, the Kyrgyz state has been consistently unable to devote sufficient resources to its struggling and tactically incapable armed and security services. Kyrgyzstan's current defense posture emphasizes an increased reliance on the CSTO and Russia as ultimate guarantors of its peace and stability. The Kyrgyz military brass does not plan on conducting independent maneuvers or fully-fledged military operations. A recent deal with Russia on the Kant airbase and an expected procurement of a substantial amount of Russian heavy weapons highlights the current emphasis on increasing security cooperation with Russia. Additionally, with the U.S. getting ready to close the Manas Training Center and possibly significantly downsize its already modest security cooperation with Kyrgyzstan, Russian and CSTO influence over the security sector can be expected to grow.

In Tajikistan, the latest COIN experiences of Rasht Valley in 2010 and Khorog in 2012 revealed the overall tactical incompetence of the Tajik armed and security forces. The inherent difficulties of operating in restrictive mountainous terrain coupled with troops' lack of operational experience underscored a critical need for the significant enhancement of basic infantry and medical skills along with a development of airlift and air-assault capabilities. As the country is projected to remain in dire economic straits and lack the financial means to modernize its military on its own, it is likely to continue relying on the Russian 201st IN DIV as the ultimate guarantor of its security, while also attempting to slowly develop a peacekeeping battalion with U.S. help. At the same time, in preparation for the "doomsday Afghanistan post-2014 scenario" the country's border 
guards will continue to be reinforced by regular army units. In these terms, receiving assistance from both Russia and the U.S. will remain important to the country's ability to stem a potential Taliban offensive.

Despite recent efforts by Turkmenistan's government to shore up its Caspian naval capabilities, Turkmenistan remains a largely marginal player in the Central Asian security realm. Protected by its doctrine of positive neutrality, the Turkmen military is only tasked with defending the state's sovereignty against external aggression, a task that, under current circumstances, it is unlikely to handle effectively. The absence of any operational experience and modern military equipment as well as an abstention from all regional military cooperation leaves the Turkmen military unprepared to deal with any external threats. However, the situation is mitigated by a perceived lack of religious extremism and external danger.

In Uzbekistan, the relative success of the armed forces' modernization efforts rooted in the need to contain the ever-looming IMU threat and its experience of responding to the 2005 Andijan crisis instill moderate optimism in the country's ability to handle a variety of domestic security challenges. Although Uzbekistan's security services' handling of the Andijan crisis was brutal and repressive, it proved effective and brought to the forefront a need for increased rapid deployment capabilities and focus on COIN operations. At the same time, the scenario of a mass insurrection in the Fergana Valley would probably challenge Uzbekistan's forces' capacity for effective independent response and potentially lead to a sparking of wider regional instability.

\section{Policy Implications for Military-to-Military Cooperation with the U.S.}

As the U.S. is considering the best and most inexpensive ways of stabilizing Central Asia after the withdrawal of ISAF forces from Afghanistan, U.S. security policy towards Central Asia will continue adapting to the changing regional dynamics.

The current unstable security situation in Tajikistan dictates that the U.S. maintains the current level of engagements with the Tajik military and continues developing Tajik peacekeeping and border protection capacities. Tajikistan's decision to host the 2014 "Mountain Eagle" exercise is expected to be an important military-to-military event serving to further enhance the current level of cooperation.

In Uzbekistan, the usage of the NDN will likely continue affecting the overall level of cooperation with the U.S. Although an eventual decrease in NDN usage along with another situation involving a violation of human rights would complicate the security and military-to-military cooperation, abandoning Uzbekistan would risk leaving U.S. unprepared to deal with the possible global consequences of a potential explosion in the Central Asia's most volatile region of Fergana Valley.

Kazakhstan's successful conduct of true multi-vector foreign policy compels the U.S. to stay involved in its current advisory role and continue emphasizing developing an already robust, by regional standards, peacekeeping capacity. At the same time, given Kazakh state's ability to finance its own military without foreign help and a perceived lack of future wide-scale internal instability, it is unrealistic to expect the current level of security cooperation to increase in the short to medium term. 
The 2014 closure of Manas Transit Center coupled with an increasing Russian involvement in the Kyrgyz security sphere make an increase in the military-to-military cooperation between Kyrgyzstan and the U.S. all but impossible. While Kyrgyzstan continues to face multiple internal and border security issues, U.S. military-to-military cooperation will likely remain limited and even be further reduced from current levels.

Turkmenistan's self-imposed doctrine of positive neutrality will continue to keep the level of military-to-military cooperation with the U.S at its current low. Turkmenistan's largely moribund military will likely remain internationally isolated and not become involved in any regional exercises. 


\section{Bibliography}

"Base Agreement Will Boost Russia-Tajikistan Relations." The Oxford Analytica Daily Brief (2013).

"Central Asia's Military Shifts Strengthen Russian Ties." The Oxford Analytica Daily Brief (2013).

"Kazakh Security Measures Address Emerging Threats." Oxford Analytica Daily Brief (2013).

. Almanac 2012: Governing and Reforming Kyrgyzstan Security Sector., 2012.

Arifhanov, Shavkat. Centralinaya Azia: Nastoiaeshee $i$ Budushee In Central Asia: Present and Future. Tashkent: Extremum Press, 2010.

Armed Forces, Kyrgyzstan. London: IHS Global Limited, 2013.

Azizov, D.. Uzbekistan Presents Army Development Strategy. Trend, 2014.

Beyshenov, Murat. "The Armed Forces of Kyrgyzstan: Brief Overview and Perspectives for Development at the Current Stage." In Almanac 2012: Governing and Reforming Kyrgyzstan Security Sector, 26. Geneva-Bishkek: Geneva Centre of the Democratic Control of the Armed Forces, 2013.

Boonstra, Jos, Erica Marat, and Vera Axynova. Security Sector Reform in Kazakhstan, Kyrgyzstan and Tajikistan: What Role for Europe?. EUCAM, 2013.

Chapter Five: Russia and Eurasia In The Military Balance 113., 2013.

Cole, Eden, and Philipp Fluri. Defence and Security Sector Institution Building in the Post-Soviet Central Asian States . Geneva: DCAF, 2007.

Gleason, Gregory. Why Russia is in Tajikistan In Comparative Strategy 20., 2001.

Hramchihin, Alexander. "Slaboe Zveno Centralinoy Azii (The Weak Link of Central Asia)." Nezavisimoe Voennoe Obozrenie (2013).

Interview with Kyrgyz Minister of Defense Taalaybek Omuraliev. Radio Azzatyk, 2013. Jennings, Gareth. "Kazakhstan Signs for Additional C295 Transport Aircraft." Jane's Defence Weekly (2013).

Kazakhstan Armed Forces. London: IHS Global Unlimited, 2013.

Kazakhstan at a Glance. Executive Summary. London: HIS Global Limited, 2012.

Kazakhstan to Spend More on Defense and Disaster Prevention. BNews.kz, 2013.

Kucera, Joshua. Turkey Promises to Boost Military Aid to Kyrgyzstan. Eurasianet.org, 2012. 
McDermott, Roger. "Tashkent Strengthens Security Ties with Moscow Ahead of NATO Drawdown." Eurasia Daily Monitor 10, no. 36 (2013).

McDermott, Roger. Central Asian security post-2014. Perspectives in Kazakhstan and Uzbekistan. Copenhagen: Danish Institute for International Studies, 2013.

Mukhin, Vladimir. "Ocheni Dorogaia Kollektivnaia Oborona (Very Expensive Collective Defense)." Nezavisimoe Voennoe Obozrenie (2013).

Nichol, Jim. Kazakhstan: Recent Developments and U.S. Interests. Washington DC: Congressional Research Service, 2013.

Nichol, Jim. Turkmenistan: Recent Developments and U.S. Interests, CRS Report for Congress. Washington, D.C.: Congressional Research Service, 2012.

Nichol, Jim. Uzbekistan: Recent Developments and U.S. Interests. Washington, DC: Congressional Research Service, 2013.

Nikolskiy, Aleksei. "\$500 Million Worth of Tanks." Vedomosti (2012).

Official: Russia to Expand Kyrgyzstan Military Airbase. Defence News, 2013.

Peyrouse, Sébastien. "Russia-Central Asia: Advances and Shortcomings of the Military Partnership." In Central Asian Security Trends: Views from Europe and Russia, 1-34. Carlisle, PA: Strategic Studies Institute, U.S. Army War College, 2011.

Procurement, Kazakhstan. London: IHS Global Unlimited, 2013.

Safronov, Ivan, Elena Chernenko, and Kabai Karabekov. Russia Will Arm Kyrgyzstan and Tajikistan. Kommersant Online, 2013.

Security, Kazakhstan. London: IHS Global Limited, 2012.

Tajikistan at a Glance. London: IHS Global Limited, 2011, 2011.

Trenin, Dmitriy, and Sébastien Peyrouse. "Central Asian Security Trends: Views from Europe and Russia." In Russia-Central Asia: Advances and Shortcomings of the Military Partnership, 1-34. Carlisle, PA: Strategic Studies Institute, U.S. Army War College, 2011.

Turkmenistan Armed Forces. London: IHS Global Limited, 2013.

Turkmenistan Executive Summary. London: IHS Global Limited, 2012.

Turkmenistan Will Not Increase the Air Defense Cooperation with the CIS Countries. RIA Novosti, 2012.

Upadhyay, Dadan. "Russia, Uzbekistan Agree to Join Hands to Meet Afghanistan Threats." Rossiyskaya Gazeta (2013).

Uzbekistan at a Glance. London: IHS Global Limited, 2013. 
Voennaia Doktrina Kyrgyzskoi Respubliki (Military Doctrine of the Kyrgyz Republic) 2012., 2012.

Voennaia Doktrina Respubliki Kazakhstan., 2011.

World Armies - Kazakhstan. London: IHS Global Unlimited, 2013.

World Armies_Uzbekistan. London: IHS Global Limited, 2013. 